\title{
ANALISIS PENGENDALIAN INTERN ATAS PIUTANG PADA PT. BPR RAJEKWESI SUMBERREJO BOJONEGORO
}

\author{
Novi Vizainiyah \\ STIE Muhammadiyah Tuban \\ Novivizainiyah198@gmail.com
}

\begin{abstract}
Internal control is a framework that consists of components that are interrelated in conducting its activities in order to control the running of the company and to secure the company's assets, to make regulations on the policy to be followed by management. The analysis used in this research is to use the concept of internal control COSO models. The purpose of this study was to determine whether the application of internal control of accounts receivable at PT. BPR Rajekwesi Sumberrejo been effective.

The location of the research at Jl. Raya Sumberrejo No. 105, Sumberrejo, Bojonegoro. PT. BPR Rajekwesi Sumberrejo a regional-owned enterprises engaged in receiving deposits in the form of loans, deposits, savings, and / or other forms. So it has a very large amount of accounts receivable. This study uses a quantitative descriptive test the internal control receivable refers to the COSO framework on the components of internal control. The results of this study showed that overall internal control of receivables is effective, can be seen in the total calculation that shows the value of 903 (located between the interval 815-1007), where management has been applying the concepts and principles of internal control.
\end{abstract}

Keyword : Internal Control, Credit Saving Loan, Account Receivables

\begin{abstract}
ABSTRAK
Pengendalian intern adalah suatu kerangka yang terdiri dari komponen-komponen yang saling berkaitan dalam melakukan kegiatannya guna mengendalikan jalannya perusahaan dan mengamankan aset perusahaan, dengan membuat peraturan atas kebijakan untuk dipatuhi oleh manajemen. Analisis yang digunakan dalam penelitian ini adalah menggunakan konsep pengendalian intern model COSO. Tujuan penelitian ini adalah untuk mengetahui apakah penerapan pengendalian intern terhadap piutang pada PT. BPR Rajekwesi Sumberrejo sudah efektif. Lokasi penelitian yang digunakan beralamatkan di Jl. Raya Sumberrejo No. 105, Sumberrejo, Bojonegoro. PT. BPR Rajekwesi Sumberrejo merupakan Badan Usaha Milik Daerah yang bergerak di bidang menerima simpanan dalam bentuk kredit, deposito berjangka, tabungan, dan/atau bentuk lainnya. Sehingga memiliki jumlah piutang yang sangat besar. Penelitian ini menggunakan uji deskriptif kuantitatif terhadap pengendalian intern piutang yang mengacu pada kerangka kerja COSO pada komponen-komponen pengendalian intern. Hasil dari penelitian ini menunjukkan bahwa secara keseluruhan pengendalian intern terhadap piutang berjalan efektif, dapat dilihat total perhitungan yang menunjukkan nilai 903 (berada diantara interval 815-1007), dimana manajemen sudah menerapkan konsep dan prinsip-prinsip pengendalian intern.
\end{abstract}

Kata kunci : Pengendalian Intern, Kredit Simpan Pinjam, Piutang Usaha

PENDAHULUAN

Latar Belakang Masalah 
Perbankan sebagai suatu lembaga keuangan yang memiliki peran penting untuk mengatur, menghimpun, dan menyalurkan dana kepada masyarakat. Fungsi utama dari perbankan Indonesia adalah menghimpun dan menyalurkan dana masyarakat serta bertujuan untuk menunjang pelaksanaan pembangunan nasional dalam rangka meningkatkan pemerataan pembangunan dan hasilnya, pertumbuhan ekonomi dan stabilitas nasional ke arah peningkatan taraf hidup rakyat banyak.

Berdasarkan Undang-undang No. 7 Tahun 2002, Bank Perkreditan Rakyat (BPR) adalah badan usaha yang menghimpun dana dari masyarakat dalam bentuk simpanan, dan menyalurkannya kepada masyarakat dalam bentuk kredit dan atau bentuk-bentuk lainnya dalam rangka meningkatkan taraf hidup rakyat (Siamat dalam Utikawati).

Piutang usaha suatu perusahaan pada umumnya merupakan bagian terbesar dari aktiva lancar serta bagian terbesar dari total aktiva perusahaan. Oleh karena itu pengendalian intern terhadap piutang usaha ini sangat penting diterapkan. Kecurangan dalam suatu siklus kerja sangat sering terjadi sehingga dapat merugikan perusahaan. Kecurangan yang mungkin terjadi pada bagaian piutang usaha adalah tidak mencatat pembayaran dari debitur dan mengantongi uangnya, menunda pencatatan piutang dengan melakukan cash lapping, melakukan pembukuan palsu atas mutasi piutang, dan lain sebagainya. Pengendalian intern adalah salah satu cara yang digunakan dalam mengantisipasi kecurangan dalam sebuah perusahaan.

Sebuah konsep pengendalian intern model Committee of Sponsoring Organizations of the Treatway Commission (COSO) adalah sebagai dasar untuk pengendalian intern. COSO memperkenalkan kerangka pengendalian (control famework) yang terdiri dari 5 komponen yaitu: lingkungan pengendalian (Control environtment), penenetuan risiko (risk assesment), aktivitas pengendalian (control activity), informasi dan komunikasi (information and communication), pengawasan dan pemantauan (monitoring). Kelima komponen pengendalian intern ini mempunyai hubungan yang erat satu sama lain. Kelima komponen tersebut merupakan sebuah bangunan rumah dimana lingkungan pengendalian merupakan pondasi dari keempat komponen lainnya. Penilaian risiko, aktivitas pengendalian dan informasi dan komunikasi menjadi pilar-pilarnya. Sedangkan monitoring menjadi atap bangunannya. Dengan demikian, sebuah pengendalian intern akan berjalan secara efektif jika kelima unsur tersebut terbangun dengan baik dan beroperasi sesuai proporsinya masing-masing (Agoes, 2012:103).

PT. BPR Rajekwesi Sumberrejo merupakan Badan Usaha Milik Daerah yang bergerak di bidang menerima simpanan hanya dalam bentuk deposito berjangka, tabungan, dan/atau bentuk lainnya. Aktivitas usaha PT. BPR Sumberrejo adalah melakukan simpan pinjam. Pemberian kredit merupakan aktivitas BPR yang paling utama dalam menghasilkan keuntungan, tetapi risiko yang terbesar dalam bank juga bersumber dari pemberian kredit.

Dari berbagai penjelasan diatas, maka penulis merasa tertarik dan perlu untuk mengadakan penelitian dalam bentuk skripsi yang penulis beri judul "Analisis Pengendalian Intern Atas Piutang pada PT. BPR Rajekwesi Sumberrejo".

\section{Rumusan Masalah}


Berdasarkan latar belakang masalah diatas, maka penulis merumuskan masalah yang akan dibahas dalam penelitian ini adalah "bagaimana penerapan sistem pengendalian intern terhadap piutang pada PT. BPR Rajekwesi Sumberrejo?

\section{Tujuan Penelitian}

Penelitian ini dilakukan dengan tujuan untuk mengetahui apakah penerapan pengendalian intern terhadap piutang PT. BPR Rajekwesi Sumberrejo sudah efektif.

\section{LANDASAN TEORI}

\section{Sistem Pengendalian Intern}

\section{Pengertian Sistem Pengendalian Intern}

Sistem pengendalian intern menurut Mulyadi (2016:129) meliputi tentang struktur organisasi, metode, dan ukuran-ukuran yang dikoordinaiskan untuk menjaga aset perusahaan, mengecek ketelitian dan keandalan data akuntansi, mendorong efisiensi dan mendorong dipatuhinya kebijakan manajemen.

\section{Unsur-unsur Pengendalian Intern Model COSO}

Suatu komite yang diorganisir oleh lima organisasi profesi yaitu IIA (Institute of Internal Auditors), AICPA, IMA (Institute of Management Accountants), FEI (Financial Executives Institute), dan AAA (American Accounting Association) pada bulan oktober 1987 menghasilkan kajian yang dinamakan COSO framework of internal control. Pada tahun 1992 COSO mengeluarkan definisi tentang pengendalian intern, COSO memandang pengendalian intern merupakan rangkaian tindakan yang menembus seluruh organisasi.

COSO mengidentifikasi lima komponen pengendalian internal yang berpengaruh terhadap kemampuan organisasi dalam mencapai sasaran pengendalian internal (Dasaratha dan Federick, 2011:134):

1) Lingkungan pengendalian

Mengacu pada faktor-faktor umum yang menetapkan sifat organisasi dan memengaruhi kesadaran karyawannya terhadap pengendalian.

2) Penetuan resiko

Identifikasi dan analisis risiko yang mengganggu pencapaian sasaran pengendalian internal.

3) Aktivitas pengendalian

Kebijakan dan prosedur yang dikembangkan oleh organisasi untuk menghadapi risiko. Aktivitas pengendalian meliputi hal-hal berikut: penelaahan kinerja, pemisahan tugas, pengendalian aplikasi, dan pengendalian umum

4) Informasi dan komunikasi

Sistem informasi perusahaan merupakan kumpulan prosedur (otomasi dan manual) dan record yang dibuat untuk memulai, mencatat, memproses, dan melaporkan kejadian pada proses entitas. Komunikasi meliputi penyediaan pemahaman mengenai peran dan tanggung jawab individu.

5) Pengawasan 
Manajemen harus mengawasi pengendalian internal untuk memastikan bahwa pengendalian organisasi berfungsi sebagaimana dimaksudkan.

\section{Piutang}

Menurut Syafi'i Syakur (2009:93) piutang usaha menunjukkan adanya klaim perusahaan kepada pihak (perusahaan) lain dalam bentuk uang, barang, jasa, atau dalam bentuk aktiva non kas lainnya yang harus dilakukan penagihan pada tanggal jatuh temponya. Piutang usaha dapat berupa tagihan yang timbul karena penjualan barang dagangan dan jasa atau penjualan aktiva lainnya yang dilakukan secara kredit dan transaksi-transaksi lain.

\section{Penelitian Terdahulu}

Penelitian yang berjudul" Analisis Pengendalian Intern Piutang Usaha pada PT. SFI Medan”. Hasil pengujian menunjukkan bahwa dari unsur-unsur pengendalian intern menururt kerangka kerja COSO, unsur penentuan resiko dan unsur aktivitas pengendalian kurang efektif, sedangkan unsur lingkungan pengendalian, unsur informasi dan komunikasi, serta unsur pengawasan atau pemantauan telah efektif.(Dian Hartati, 2009)

Penelitian yang berjudul “Analisis Prosedur Pengendalian InternPiutang Usaha Pada Astra Credit CompaniesCabang Makassar”. Hasil pengujian pengendalian intern piutang usaha yang diterapkan di Astra Credit Companies Cabang Makassar sudah berjalan cukup efektif dimana manajemen perusahaan sudahmenerapkan konsep-konsep dasar dan prinsip-prinsip pengendalian intern. (Sulaeman, 2012)

\section{Kerangka Konseptual}

Kerangka pemikiran di bawah ini menggambarkan bahwa pengelolaan piutang dilakukan melalui pengendalian intern terhadap piutang yang ada di PT. BPR Rajekwesi dengan mengacu pada model COSO, sehingga diharapkan dengan adanya pengendalian intern dapat meningkatkan kinerja perusahaan.

\section{Gambar 2.1 Kerangka Konseptual}

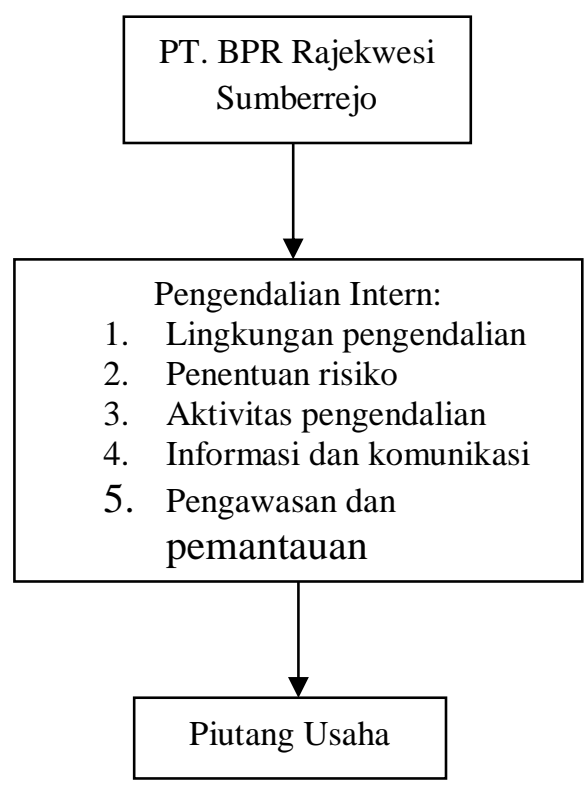

\section{METODE PENELITIAN}




\section{Pendekatan Penelitian}

Menurut Sugiyono (2014:80) pendekatan penelitian merupakan suatu rancangan kerja penelitian yang akan digunakan dalam penelitian, oleh karena itu rencana penelitian harus ditetapkan terlebih dahulu sebelum penelitian dilakukan.

Pendekatan penelitian yang digunakan dalam penelitian ini adalah pendekatan kuantitatif. Metode kuantitatif menurut Sugiyono (2014:8) adalah metode penelitian yang berlandaskan pada filsafat positivisme, digunakan untuk meneliti pada populasi atau sampel tertentu, penggumpulan data menggunakan instrument penelitian

\section{Obyek Penelitian}

Objek penelitian ini dilakukan di PT BPR Rajekwesi Sumberrejo yang beralamatkan di Jl. Raya Sumberrejo No. 105, Sumberrejo, Bojonegoro, Jawa Timur.

\section{Populasi dan Teknik Pengambilan Sampel}

1. Populasi

Populasi menurut Sugiyono (2014:80) adalah wilayah generalisasi yang terdiri atas: objek/subjek yang mempunyai kualitas dan karakteristik tertentu yang ditetapkan oleh peneliti untuk dipelajari dan kemudian ditarik kesimpulannya. Populasi yang akan di teliti adalah seluruh karyawan yang bekerja pada PT BPR Rajekwesi Sumberrejo.

2. Sampel

Menurut Sugiyono (2014:81) sampel adalah bagian dari jumlah dan karakteristik yang dimiliki oleh populasi tersebut. Teknik pengambilan sampel yang digunakan dalam penelitian ini adalah nonprobability sampling. Metode ini memilih sampel dari elemen populasi (orang/kejadian) yang datanya mudah di dapat oleh si peneliti. Dalam penelitian ini sampel yang digunakan adalah karyawan PT. BPR Rajekwesi Sumberrejo.

\section{Metode pengumpulan data}

Teknik pengumpulan data yang dilakukan oleh penulis adalah sebagai berikut:

1. Wawancara

Menurut Esterberg dalam Sugiyono (2014:231) wawancara adalah merupakan pertemuan dua orang untuk bertukar informasi dan ide melalui tanya jawab, sehingga dapat dikonstruksikan makna dalam suatu topik tertentu. wawancara ini dilakukan dengan tujuan untuk memperoleh informasi.

2. Teknik observasi

Menurut Sutrisno Hadi dalam Sugiyono (2014:145) mengemukakan bahwa, observasi merupakan suatu proses yang kompleks, suatu proses yang tersusun dari berbagai proses biologis dan psikhologis. Dua di antara yang terpenting adalah proses-proses pengamatan dan ingatan.

3. Teknik kuesioner

Menurut Sugiyono (2014:142) kuesioner merupakan teknik pengumpulan data yang dilakukan dengan cara member seperangkat pertanyaan atau pernyataan tertulis kepada responden untuk dijawabnya.

\section{Skala Pengukuran}


Skala pengukuran yang digunakan dalam penelitian ini adalah dengan menggunakan skala 5 point, sebagai berikut:

Tabel 3.1 : Pemberian Skor

\begin{tabular}{|l|l|}
\hline SS = Sangat Setuju & Skor 5 \\
\hline ST $=$ Setuju & Skor 4 \\
\hline RG = Ragu-ragu & Skor 3 \\
\hline TS = Tidak Setuju & Skor 2 \\
\hline STS = Sangat Tidak Setuju & Skor 1 \\
\hline
\end{tabular}

Menurut Habibie (2013) perhitungan total interval untuk menghitung tingkat pengendalian intern piutang usaha dengan cara sebagai berikut:

Nilai Tertinggi $=$ Total Pertanyaan $\mathrm{x}$ Total Responden $\mathrm{x}$ Bobot Tertinggi

Nilai Terendah $=$ Total Pertanyaan $\mathrm{x}$ Total Responden $\mathrm{x}$ Bobot Terendah Jarak = Nilai Tertinggi - Nilai Terendah

Penilaian terhadap responden tersebut dapat dikelompokkan ke dalam analisis pengendalian intern piutang usaha menjadi beberapa kategori sebagai berikut:

Tabel 3.2 : Kategori Penilaian

\begin{tabular}{|l|l|l|}
\hline No. & Nilai & \multicolumn{1}{|c|}{ Keterangan } \\
\hline 1 & TE & Tidak Efektif \\
\hline 2 & KE & Kurang Efektif \\
\hline 3 & CE & Cukup Efektif \\
\hline 4 & E & Efektif \\
\hline 5 & SE & Sangat Efektif \\
\hline
\end{tabular}

Menurut Habibie (2013) efektifitas pengendalian intern piutang usaha dapat dihitung dengan rumus sebagai berikut:

$$
\frac{\text { jumlah keseluruhan jawaban }}{\text { jumlah keseluruhan pernyataan }} \times 24
$$

Apabila unsur pengendalian intern diatas dipecah kedalam lima komponen pengendalian intern model COSO, maka dapat dihitung sebagai berikut:
1) Lingkungan pengendalian (LP)$$
=\frac{\text { jumlah jawaban } L P}{\text { jumlah pernyataan }} \times 24
$$
2) Penilaian risiko (PR)$$
=\frac{\text { jumlah jawaban } P R}{\text { jumlah pernyataan }} \times 24
$$
3) Aktivitas pengendalian (AP) $=\frac{\text { jumlah jawaban } A P}{\text { jumlah pernyataan }} \times 24$
4) Informasi dan komunikasi (IK) $=\frac{\text { jumlah jawaban IK }}{\text { jumlah pernyataan }} \times 24$
5) Pengawasan dan Pemantauan (PP) $=\frac{\text { jumlah jawaban } P P}{\text { jumlah pernyataan }} \times 24$

\section{Metode Analisis Data}


Analisis data yang dilakukan dalam penelitian ini adalah dengan metode deskriptif. Metode deskriptif adalah metode analisis dengan terlebih dahulu mengumpulkan data yang ada kemudian diklarifikasi, dianalisis, selanjutnya diinterpretasikan sehingga dapat memberikan gambaran yang jelas mengenai keadaan yang diteliti.

\section{PEMBAHASAN}

\section{Sejarah Berdirinya Perusahaan}

Bank Perkreditan Rakyat atau yang biasa disingkat BPR adalah salah satu lembaga keuangan yang bergerak di bidang jasa UMKM. BPR merupakan lembaga perbankan di bawah pengawasan Bank Indonesia. BPR tidak langsung berdiri begitu saja, tetapi melalui tahapan-tahapan selama bertahun-tahun. Berawal dari keinginan untuk membantu para petani, pegawai, dan buruh untuk melepaskan diri dari jerat rentenir yang memberikan kredit dengan bungga yang tinggi, lembaga perkreditan inilah mulai didirikan.

Bank merupakan salah satu lembaga yang banyak digunakan oleh kalangan masyarakat, karena bank digunakan oleh perusahaan, badan-badan usaha, maupun perorangan dalam penyimpanan dananya, sehingga akan sangat membutuhkan sistem operasional kerja yang efektif dan efisien dalam pelayanan terhadap nasabah. PT. BPR merupakan salah satu bank yang memberikan pelayanan terhadap para nasabahnya yang dimana pada sistem kerjanya bank perkreditan rakyat ini mengelolah dana dari para nasabah beruapa tabungan dan deposito yang kemudian disalurkan keapada nasabah sebagai kredit dalam sitem yang sangat lunak serta fleksibel bagi para nasabah/peminjam yang mayoritas adalah penduduk desa.

PT. BPR Rajekwesi didirikan berdasarkan Surat Penetapan Pengadilan Negeri Surabaya Nomor: 05/P.C.NOT/1990.P.N-SBY tanggal 21 (dua puluh satu) Agustus 1990 (seribu Sembilan ratus Sembilan puluh) pengganti NOOR IRAWATI, Sarjana Hukum, Notaris di Surabaya.

Sesuai dengan pasal 2 Anggaran Dasar Bank, maksud dan tujuan pendirian Bank adalah melakukan kegiatan usaha yakni menghimpun dana masyarakat dalam bentuk deposito dan tabungan.

\section{Analisis Pembahasan dan Hasil Penelitian}

Didirikanya sebuah bank mempunyai tujuan tertentu, seperti pendirian PT. BPR Rajekwesi yang mempunyai tujuan untuk mensejahterahkan para nasabahnya. PT. BPR Rajekwsei merupakan Bank Perkreditan Rakyat, yang tugasnya adalah menghimpun dana dari nasabah dan menyalurkannya kembali, disini penghimpunan dana tersebut berupa tabungan dan deposito yang dilakukan oleh nasabah, sedangkan untuk penyaluran dana berupa pemberian kredit kepada nasabah.

Pemaparan tersebut memberikan dorongan dari pihak bank untuk melakukan pengendalian intern pada piutang usaha, agar dapat meminimalisir terjadinya hal - hal yang tidak diinginkan oleh bank. Pengendalian intern mempunyai berbagai komponen yang harus dipenuhi demi kelancaran dari tujuan peberapan pengendalian intern.

Dimana pada penilitian ini komponen dari pengendalian intern tersebut akan dijadikan sebagai tolak ukur apakah sudah sesuai dan telah mencapai target yang di inginkan pada PT. BPR.

Berdasarkan penelitian yang dilakukan oleh penulis terhadap prosedur kerja di PT. BPR Rajekwesi Sumberrejo, diketahui bahwa manajemen perusahaan memberikan perhatian yang baik terhadap pengendalian intern atas piutang usaha, baik dari segi pengelolaan hingga pengawasan piutang tersebut. 
Pengendalian intern piutang usaha pada PT. BPR Sumberrejo sudah berjalan efektif. Hal ini diketahui bahwa manajemen perusahaan memberikan perhatian lebih terhadap pengendalian intern piutang usaha, baik dari segi pengelolaan hingga pengawasan piutang tersebut. Oleh sebab itu, Lingkungan Pengendalian pada PT. BPR Rajekwesi Sumberrejo sudah berjalan efektif. Hal ini ditandai dengan indepensi komite audit yang berada langsung dibawah naungan komisaris, begitu pula konsep pengendalian yang telah diterapkan oleh jajaran direksi sudah berjalan dengan efektif.

Penentuan risiko pada PT. BPR Rajekwesi cukup efektif, karena manajemen kadang kala mendapati calon nasabah yang tidak berkualitas sehingga nantinya dapat merugikan bank. Aktivitas pengendalian intern pada PT. BPR Rajekwesi sudah berjalan efektif yaitu dengan adanya pemisahan tugas yang jelas. Informasi dan komunikasi terhadap piutang usaha telah berjalan sangat efektif, hal ini ditandai dengan akses yang mudah dan cepat dalam memperoleh data mengenai piutang usaha dan mengimbangi pihak-pihak yang berkaitan dengan piutang usaha itu sendiri. Pengawasan dan pemantauan terhadap piutang usaha telah berjalan dengan baik dan efektif. Pimpinan perusahaan selalu mengingatkan kepada para karyawan atas segala informasi penting yang harus dilakukan oleh mereka.

Berikut ini adalah skor kuesioner pengendalian intern atas piutang usaha pada PT. BPR Rajekwesi yang dilakukan oleh peneliti. Dalam penelitian ini pernyataan tersebut ditetapkan secara spesifik oleh peneliti yang selanjutnya disebut sebagai variabel penelitian. Perhitungan total interval untuk menghitung "Tingkat Pengendalian Intern Piutang" dilakukan dengan cara sebagai berikut (Habibie, 2013) :

Nilai tertinggi $=$ Total pertanyaan $\times$ Total Responden $\times$ Bobot tertinggi

$$
\begin{aligned}
& =24 \times 10 \times 5 \\
& =1200
\end{aligned}
$$

Nilai terendah $=$ Total pertanyaan $\times$ Total Responden $\times$ Bobot terendah

$$
\begin{aligned}
& =24 \times 10 \times 1 \\
& =240
\end{aligned}
$$

Jarak = Nilai tertinggi - Nilai terendah

$$
\begin{aligned}
& =1200-240 \\
& =960
\end{aligned}
$$

Perhitungan interval kelas dilakukan dengan cara berikut ini:

Jarak/kelas $=960 / 5=192$

Untuk mengetahui tingkat efektivitas pengendalian intern atas piutang, peneliti menggunakan perhitungan yang menunjukkan seberapa besar efektivitas pengendalian intern atas piutang pada PT. BPR Rajekwesi Sumberrejo.

\section{Pengendalian Intern atas Piutang}

Keterangan:

$$
\begin{array}{ll}
\mathrm{TS} & =12 \times 1=12 \\
\mathrm{KS} & =33 \times 2=66 \\
\mathrm{RR} & =20 \times 3=60 \\
\mathrm{~S} & =110 \times 4=440 \\
\mathrm{SS} & =65 \times 5=325
\end{array}
$$




\section{3}

Analisis pengendalian intern piutang

$$
=\frac{\text { jumlah keseluruhan jawaban } \times 24}{\text { jumlah keseluruhan pernyataan }}
$$

$$
\begin{aligned}
& =\frac{903 \times 24}{24} \\
& =903 \text { (berada diantara interval 815-1007) } \\
& =\text { Efektif }
\end{aligned}
$$

Hal ini menunjukkan bahwa secara keseluruhan pengendalian intern atas piutang pada PT. BPR Rajekwesi Sumberrejo sudah berjalan efektif.

Apabila unsure pengendalian intern tersebut dipecah kedalam lima komponen, maka efektivitas pengendalian intern atas piutang menurut model COSO dapat dihitung dengan cara sebagai berikut:

1. Lingkungan Pengendalian

$$
\begin{array}{ll}
\mathrm{TS} & =3 \times 1=3 \\
\mathrm{KS} & =9 \times 2=18 \\
\mathrm{R} & =2 \times 3=6 \\
\mathrm{~S} & =15 \times 4=60 \\
\mathrm{SS} & =11 \times 5=55
\end{array}
$$

Analisis lingkungan pengendalian

$$
\begin{aligned}
& =\frac{\text { jumlah keseluruhan jawaban } \times 24}{\text { jumlah keseluruhan pernyataan }} \\
& =\frac{142 \times 24}{4} \\
& =852 \text { (berada diantara 815-1007) } \\
& =\text { Efektif }
\end{aligned}
$$

Hal ini menunjukkan bahwa unsur lingkungan pengendalian pada PT. BPR Rajekwesi berjalan efektif.

2. Penentuan risiko

$$
\begin{aligned}
& \mathrm{TS}=4 \times 1=4 \\
& \mathrm{KS}=6 \times 2=12 \\
& \mathrm{R}=1 \times 3=3 \\
& \mathrm{~S}=8 \times 4=32 \\
& \mathrm{SS}=1 \times 5=5 \\
& \hline
\end{aligned}
$$

Analisis penilaian risiko

$$
\begin{aligned}
& =\frac{\text { jumlah keseluruhan jawaban } \times 24}{\text { jumlah keseluruhan pernyataan }} \\
& =\frac{56 \times 24}{2} \\
& =672 \text { (berada diantara 622-814) } \\
& =\text { Cukup Efektif }
\end{aligned}
$$

Hal ini menunjukkan bahwa unsur penentuan risiko pada PT. BPR Rajekwesi berjalan cukup efektif.

3. Aktivitas pengendalian

$$
\begin{aligned}
\mathrm{TS} & =5 \times 1=5 \\
\mathrm{KS} & =18 \times 2=36 \\
\mathrm{R} & =14 \times 3=42
\end{aligned}
$$




$$
\begin{aligned}
& \mathrm{S} \quad=44 \times 4=176 \\
& \mathrm{SS}=29 \times 5=145
\end{aligned}
$$

Analisis aktivitas pengendalian $=\frac{\text { jumlah } \text { keseluruhan } \text { jawaban } \times 24}{\text { jumlah keseluruhan pernyataan }}$

$$
\begin{aligned}
& =\frac{404 \times 24}{11} \\
& =881 \text { (berada diantara 815-1007) } \\
& =\text { Efektif }
\end{aligned}
$$

Hal ini menunjukkan bahwa unsur aktivitas pengendalian pada PT. BPR Rajekwesi berjalan efektif.

4. Informasi dan komunikasi

$$
\begin{aligned}
& \mathrm{TS}=0 \times 1=0 \\
& \mathrm{KS}=0 \times 2=0 \\
& \mathrm{R}=0 \times 3=0 \\
& \mathrm{~S}=21 \times 4=84 \\
& \mathrm{SS}=19 \times 5=95 \\
& \hline
\end{aligned}
$$

Analisis informasi dan komunikasi $=\frac{\text { jumlah keseluruhan jawaban } \times 24}{\text { jumlah keseluruhan pernyataan }}$

$$
\begin{aligned}
& =\frac{179 \times 24}{4} \\
& =1074 \text { (berada diantara 1008-1200) } \\
& =\text { Sangat Efektif }
\end{aligned}
$$

Hal ini menunjukkan bahwa unsur informasi dan komunikasi pada PT. BPR Rajekwesi berjalan sangat efektif.

5. Pengawasan dan pemantauan

$$
\begin{aligned}
\mathrm{TS} & =0 \times 1=0 \\
\mathrm{KS} & =0 \times 2=0 \\
\mathrm{R} & =3 \times 3=9 \\
\mathrm{~S} & =22 \times 4=88 \\
\mathrm{SS} & =5 \times 5=25 \\
\hline & 122
\end{aligned}
$$

Analisis pengawasan dan pemantauan

$$
\begin{aligned}
& =\frac{\text { jumlah keseluruhan jawaban } \times 24}{\text { jumlah keseluruhan pernyataan }} \\
& =\frac{122 \times 24}{3} \\
& =976 \text { (berada diantara 815-1007) } \\
& =\text { Efektif }
\end{aligned}
$$

Hal ini menunjukkan bahwa unsur pengawasan dan pemantauan pada PT. BPR Rajekwesi berjalan efektif.

Perhitungan terhadap 10 reponden tersebut dapat di kelompokkan ke dalam analisis pengendalian intern piutang usaha menjadi beberapa kategori, yaitu antara lain:

Tabel 4.2 : Kategori Kelas Interval BPR Rajekwesi Sumberrejo

\begin{tabular}{|l|l|l|l|}
\hline No. & Kelas Interval & Nilai & Keterangan \\
\hline
\end{tabular}




\begin{tabular}{|l|l|l|l|}
\hline 1 & $236-428$ & TE & Tidak Efektif \\
\hline 2 & $429-621$ & KE & Kurang Efektif \\
\hline 3 & $622-814$ & CE & Cukup Efektif \\
\hline 4 & $815-1007$ & E & Efektif \\
\hline 5 & $1008-1200$ & SE & Sangat Efektif \\
\hline
\end{tabular}

Sumber : (Habibie, 2013)

\section{SIMPULAN DAN SARAN}

\section{Simpulan}

Berdasarkan hasil analisis pengendalian intern atas piutang pada PT. BPR Rajekwesi Sumberrejo bahwa secara keseluruhan pengendalian intern di PT. BPR Rajekwesi Sumberrejo sudah berjalan efektif, dapat dilihat total perhitungan yang menunjukkan nilai 903 (berada diantara interval 815-1007) dengan menunjukkan keterangan efektif, hal ini dapat dilihat dari:

1. Lingkungan pengendalian terhadap piutang pada PT. BPR Rajekwesi dengan total perhitungan dengan jumlah 852 yang (berada dalam kelas interval 815-1007) yang menunjukkan bahwa lingkungan pengendalian sudah berjalan secara efektif, hal ini ditandai dengan perusahaan sudah menerapkan SOP (standard operating procedures) pada divisi collection.

2. Penentuan risiko terhadap piutang berjalan dengan cukup efektif dengan total perhitungan dengan jumlah 672 yang berada dalam kelas interval 622-814, hal ini ditandai dengan kurangnya kehati-hatian manajemen dalam mendapati calon nasabah yang tidak berkualitas sehingga nantinya dapat merugikan perusahaan dan kurangnya apresiasi terhadap fungsi yang melakukan penagihan piutang yang tidak di asuransikan oleh perusahaan.

3. Aktivitas pengendalian intern terhadap piutang pada PT. BPR Rajekwesi Sumberrejo sudah berjalan efektif yaitu dengan adanya pemisahan tugas yang jelas antara bagian pemegang piutang dengan fungsi lainnya. Hal ini dapat dilihat dari perhitungan yang dengan jumlah 881 (berada diantara 8151007) yang menunjukkan bahwa hasilnya sudah efektif.

4. Informasi dan komunikasi pada PT. BPR Rajekwesi Sumberrejo telah diterapkan sangat efektif dan baik. Hal ini ditandai dengan penyampaian informasi yang baik yang disampaikan oleh manajemen kepada bawahannya maupun informasi yang berasal dari karyawan kepada manajemen. Hal ini dapat dilihat dengan perhitungan yang mempunyai jumlah 1074 (berada diantara 1008-1200) dengan keterangan sangat efektif.

5. Pengawasan dan pemantauan terhadap piutang pada PT. BPR Rajekwesi telah berjalan efektif, baik pengawasan yang dilakukan oleh pimpinan maupun audit terhadap piutang oleh komite audit. Hal ini dilihat dari perhitungan yang menunjukkan nilai jumlah 976 (berdaa diantara 815-1007) dengan keterangan efektif. 


\section{Saran}

1. Sebaiknya dalam melalukan survey terhadap calon nasabah, kondisi calon nasabah harus diperhatikan dengan teliti. Sehingga diharapkan dapat memperoleh nasabah yang berkualitas, yang nantinya akan mengurangi risiko jumlah piutang tak tertagih semakin kecil.

2. Sebaiknya pada fungsi penagihan mendapatkan asuransi saat mereka melakuka tugasnya, agar mereka bisa lebih bersemangat dalam menjalankan tugasnya.

\section{DAFTAR PUSTAKA}

Agoes, Sukrisno. 2011. Auditing. Edisi ke empat. Buku satu. Salemba Empat. Jakarta

Habibie, Nabila. Jurnal EMBA. "Analisis Pengendalian Intern Piutang Usaha pada PT ADIRA Finance Cabang Manado". Vol.1 No.3 Juni 2013, Hal.494-502.

Hartati, Dian. 2009. Skripsi. "Analisis Pengendalian Intern Piutang Usaha pada PT. SFI Medan". Universitas Sumatera Utara Medan

Mulyadi. 2016. Sistem Akuntansi. Edisi ke-4. Salema Empat. Jakarta

Rama, Dasaratha V. dan Jones, Frederick L. 2011. Sistem Informasi Akuntansi. Salemba Empat. Jakarta

Reeve, James M, dkk. 2007. Pengantar Akuntansi Adaptasi Indonesia. Buku satu. Salemba Empat. Jakarta

Romney, Marshall B. dan Paul John Steindart. (2016). Sistem Informasi Akuntansi. Cetakan ketiga. Salemba Empat. Jakarta

Sugiyono. 2014. Metode Penelitian Kuanatitatif Kualitatif dan R\&D. Cetakan ke-21. Alfabeta. Bandung

Sulaeman. 2012. Skripsi. "Analisis Prosedur Pengendalian Intern Piutang Usaha Pada Astra Credit CompaniesCabang Makassar".

Syakur, Ahmad Syafi”'i. 2009. Intermediate Accounting. AV Publisher. Jakarta

Utikawati. "Analisis Pengendalian Intern Atas Piutang Pada Pd Bpr Bkk Kendal Kantor Pusat Operasional Dan Pd Bpr Bkk Kendal Cabang Brangsong”. Universitas Dian Nuswantoro Semarang 